\title{
Gênero e política no jornalismo brasileiro*
}

\section{RESUMO}

A partir de uma ampla amostra do noticiário de telejornais e de revistas semanais de informação, o paper analisa a representação da mulher na política brasileira. Parte-se da compreensão que, além dos desafios de concorrer e se eleger, as mulheres enfrentam dificuldades específicas para ascender às posições centrais do campo político. A sobrevivência de estereótipos de gênero constrange sua ação política e a visibilidade desta ação no noticiário jornalístico, num processo que se realimenta. Isto é, o âmbito considerado "próprio" para a política feminina é também aquele que menos impulsiona as carreiras políticas e que possui menor visibilidade na cobertura jornalística da política.

\section{PALAVRAS-CHAVE}

gênero

política

jornalismo

\section{ABSTRACT}

This paper analyses representations of women in brazilian politics based on a large sample of brazilian daily television news and weekly news magazines. We understand that, besides the challenges taken by women to becomecandidates and run for public offices, they face specific difficulties to get to central positions in the political field. Gender stereotypes remain, limiting women's political action and its visibility in thenews, in a process in which one of these terms feeds back the other. In other words, the scope that is considered "proper" for women in politics is also one that weekly impels their carriers and has less visibility in political news.

\section{KEY WORDS}

gender

politics

journalism

\section{Luis Felipe Miguel}

Professor do departamento de Ciência Política da UNB/DF/BR

Ifelipemiguel@uol.com.br

\author{
Flávia Biroli \\ Professora do departamento de Psicologia Geral e Experimental da \\ UNB/DF/BR \\ fbiroli@terra.com.br
}

Este paper apresenta resultados ainda iniciais de uma pesquisa que se estabelece na confluência entre três temas: gênero, política e mídia. Embora haja tradição consolidada de trabalho acadêmico para cada um dos pares de temas (investigações sobre gênero e política, sobre política e mídia, sobre gênero e mídia), a interseção das três temáticas ainda é um campo pouco estudado, na literatura internacional e no Brasil. Trata-se de uma questão importante, na medida em que a visibilidade nos meios de comunicação de massa é um fator fundamental na produção de capital político nas sociedades contemporâneas. A mídia, como se verá adiante, é entendida na pesquisa como uma esfera de representação. Trata-se de um espaço privilegiado de difusão de representações do mundo social e que, por isso mesmo, se estabelece como momento de uma representação especificamente política.

O paper busca avançar na discussão sobre de que forma a sobrevivência de estereótipos de gênero constrange a ação política das mulheres e a visibilidade desta ação no noticiário jornalístico, num processo que se realimenta. Isto é, o âmbito considerado "próprio" para a política feminina - questões sociais, família, assistência social, meio-ambiente etc. - é também aquele que menos impulsiona as carreiras políticas e que possui menor visibilidade na cobertura jornalística da política. O que coloca as mulheres na política diante de um dilema: enfrentar os estereótipos, arcando com o ônus simbólico de assumir uma postura "desviante", ou adequar-se a ele, entendendo que seu caminho para as posições centrais do campo político será mais longo, incerto e atribulado.

Ao introduzir o conceito de "campo político", no sentido a ele atribuído por Pierre Bourdieu, o paper permite um avanço nas discussões sobre a paridade política entre homens e mulheres, entendendo que a mera presença no parlamento não representa capacidade igual de influência na elaboração da lei, na formulação de políticas e na produção das representações simbólicas do mundo social. Ao vincular a visibilidade na mídia e a ação política, dota a discussão de um modelo mais complexo e mais apropriado para entender a dinâmica política atual. A visibilidade na mídia compõe de várias maneiras o capital político: tem efeitos sobre as relações entre os líderes e os cidadãos comuns; tem efeitos sobre os processos de valorização, reconhecimento e desgaste público do político diante dos cidadãos comuns e dos seus pares; pode significar um acréscimo de visibilidade e relevância ao político no próprio campo político (na política parlamentar e/ou partidária, por exemplo).

Para testar as hipóteses da pesquisa, foi realizado o acompanhamento do noticiário político em diferentes veículos de comunicação - os telejornais Jornal Nacional, 
Jornal da Band e SBT Brasil e as revistas semanais Veja, Época e Carta Capital - em três diferentes períodos de três meses cada, entre 2006 e 2007. Os dados ainda estão em processo de tabulação e análise; o que aqui se apresenta é uma aproximação inicial com o material resultante da pesquisa empírica.

\section{Sumário de diretrizes teóricas}

Um campo é um sistema de relações sociais que estabelece como legítimos certos objetivos, que assim se impõem "naturalmente" aos agentes que dele participam. Esses agentes, por sua vez, interiorizam o próprio campo, incorporando suas regras, também de maneira "natural", em suas práticas (o que Bourdieu chama de habitus). Os campos buscam autonomia, como Bourdieu demonstrou em vários estudos: buscam ser geridos por suas próprias regras, estabelecer seus próprios critérios de consagração, de distribuição de capital simbólico. Mas não são estanques. Não é possível entender o campo político, por exemplo, sem observar a influência do campo econômico e do campo da mídia ${ }^{1}$.

O conceito de campo permite avançar no entendimento da interação entre mídia e política, duas esferas que se guiam por lógicas diferentes, mas que interferem uma na outra (Miguel, 2002). Podemos identificar quatro aspectos essenciais da influência da mídia sobre a política:

a. na forma do discurso político, que se altera para se adaptar aos novos meios;

b. na formação da agenda pública (e conseqüente busca da "geração do fato político" midiático);

c. na delimitação do espaço da política, isto é, na definição do que é socialmente entendido como pertencente à esfera da política; $\mathrm{e}$

d. na gestão da visibilidade e na produção de capital político, o aspecto que interessa mais de perto a este paper.

O que se observa é que a visibilidade na mídia é, cada vez mais, componente essencial da produção do capital político. A presença em noticiários e talk-shows parece determinante do sucesso ou fracasso de um mandato parlamentar ou do exercício de um cargo executivo, na medida em que deve acrescentar algo ao capital político próprio do ocupante. Da mesma maneira, a celebridade midiática tornou-se um ponto de partida seguro para quem deseja se lançar na vida política - na forma, dependendo do perfil de cada um, de uma candidatura às eleições ou de um convite para uma função governamental. A mídia adquiriu um forte peso na formação do capital político, condicionando, em alguma medida, as trajetórias políticas, uma vez que a ausência de visibilidade nos meios de comunicação parece ser um empecilho sério para quem almeja os cargos eletivos mais importantes do poder executivo. Mas a mídia não possui o monopólio da produção ou distribuição deste capital; e o campo político (graças ao peso dos agentes políticos de carreira mais tradicional) trata, por vezes com sucesso, de impor limites à influência da mídia, através da desvalorização simbólica dos tipos de notoriedade mais estreitamente associados aos meios de comunicação de massa.

O acesso à mídia - e, em particular, ao noticiário, que é o mais relevante aqui -, porém, é condicionado pelas percepções dos agentes do campo jornalístico sobre o que é notícia e quem está dotado de autoridade para falar sobre determinadas questões. Isto é: como se explica a exclusão de negros e mulheres de posições de destaque nos noticiários, em relação a brancos e homens (como mostram os dados da pesquisa, discutidos em seguida neste paper)? Recorrendo mais uma vez a Bourdieu e ao conceito de campo, é possível compreender as exclusões, censuras e silêncios, em grande parte, como produto do funcionamento do próprio campo, com destaque para a internalização de regras e disposições pelos agentes, situados em formas específicas de distribuição do capital simbólico dentro dele, inseridos em disputas internas e na dinâmica imposta pela concorrência entre os veículos. No caso, como produto, também, das complexas relações que se estabelecem entre os campos da mídia e da política.

Nas palavras de Bourdieu,

toda expressão é um ajustamento entre um interesse expressivo e uma censura constituída pela estrutura do campo em que ocorre esta expressão, e este ajustamento é o produto de um trabalho de eufemização podendo chegar até o silêncio, limite do discurso censurado. Este trabalho de eufemização leva a produzir algo que é um acordo de compromisso, uma combinação do que era para ser dito, que tinha como objetivo ser dito, e do que poderia ser dito dada a estrutura constitutiva de um certo campo. Dito de outra maneira, o dizível num certo campo é o resultado daquilo que se poderia chamar de 'dar forma': falar é dar formas (Bourdieu, 1983, p. 108).

As diferenças de gênero, tomadas como diferenças estruturais, têm a mídia como parte de procedimentos que reforçam a estrutura de relações e interações constituída (Young, 1998, p. 93). A mídia compõe esses procedimentos na medida em que difunde visões da realidade social que tendem a confirmar e naturalizar as visões já incorporadas pelos agentes (homens e mulheres) em relação às hierarquias de gênero. As divisões entre público e privado são, nesse sentido, exemplares. A confirmação do "pertencimento" de mulheres e homens a temas e funções vinculados à esfera pública ou à esfera privada, de acordo com as definições e relações historicamente definidas para essas esferas, é uma confirmação prospectiva das hierarquias ligadas à inserção nessas esferas e da divisão do trabalho que implicam. Prospectiva no sentido de que, ao "constatar" a realida- 
de presente, potencializa sua realização no futuro, isto é, sua permanência.

\section{Qualidades que tendem a ser associadas à fala feminina, como a emotividade, desvalorizam 0 discurso no interior do campo político.}

A noção de perspectiva, tal como trabalhada por Iris Marion Young $(1998,2001)$, permite avançar nessa discussão. Posições diversas na estrutura social (vinculadas a gênero, cor, classe, orientação sexual etc.) levam a padrões diferenciados de experiências de vida, que conformam as perspectivas sociais dos agentes. Young julga que, da mesma forma que interesses e valores, tais perspectivas devem ser levadas em conta na composição dos órgãos representativos. Afinal, um branco pode advogar pelos interesses do movimento negro ou um homem pode abraçar os valores do feminismo, mas nem um nem outro terão acesso às experiências socialmente estruturadas que são impostas aos integrantes destes grupos subalternos - a vivência do racismo ou do machismo.

A ausência destas perspectivas nos espaços de deliberação e decisão reduz o conhecimento social neles presente, comprometendo sua justiça e representatividade. $\mathrm{Na}$ argumentação da autora, pode-se observar a vinculação, por um lado, entre dominação, opressão e a naturalização das perspectivas dos grupos dominantes e, por outro, entre o aprofundamento da democracia e a possibilidade de que diferentes perspectivas estejam representadas, constituindo o que se entende por público.

A mídia, como esfera de representação (Miguel, 2003), participa de maneira privilegiada das dinâmicas por meio das quais vozes e perspectivas distintas são dadas à visibilidade $\mathrm{e}$, em certo sentido, ganham status e valor público. O reconhecimento de que os grupos sociais diversos existem politicamente, istoé, constituem perspectivas específicas que não são redutíveis a valores e discursos políticos supostamente universais, toca diretamente nas questões relativas à pluralidade e objetividade na mídia.

Nesse ponto, é possível articular a visão de Young a noções centrais aos argumentos de Pierre Bourdieu. Para o sociólogo francês, a dominação tem como de seus aspectos a imposição de perspectivas específicas como pontos de vista universais, de modo que uma posição social (de poder) constitua a norma para as demais - "é o ponto de vista dos que dominam direta ou indiretamente o Estado e que, por meio do Estado, constituíram seu ponto de vista em ponto de vista universal, ao cabo de lutas contra visões concorrentes" (Bourdieu, 2001, p. 211). São, ainda, nesse sentido, as rotinas produtivas na mídia, com seus objetivos específicos, assim como os pontos de vista dos que controlam as empresas e têm posições de poder na orientação cotidiana da produção jornalística, que se impõem como visões objetivas da realidade social, na medida em que a mídia reivindica para si o caráter de imparcialidade.

$\mathrm{O}$ apagamento das vozes vinculadas às diferentes perspectivas sociais significaria, como visto, o apagamento das trajetórias no que elas têm de politicamente significativas, na medida em que permitem que sejam vislumbrados aspectos da realidade social - e dos problemas e demandas dos grupos que nela se inserem e se relacionam - que não se tornam visíveis, da mesma maneira, pela expressão das trajetórias e experiências de outros grupos. O campo político, assim como outros, não é neutro em relação às diferentes perspectivas sociais. Seus critérios de ingresso, bem como o habitus que impõe àqueles que dele participam, implicam em pesados custos de adaptação a indivíduos oriundos de determinadas posições sociais, ao passo que outros neles encontram espelhado seu padrão de comportamento "natural". O próprio Bourdieu observa como a linguagem exigida pelo campo político se afasta da linguagem corrente dos grupos dominados. A eles, então, resta a opção de se aferrar às suas formas próprias de expressão, mas pagando o preço não serem ouvidos no campo político, ou mimetizar as formas dominantes, traindo a experiência social que se buscava transmitir (Bourdieu, 1979, p. 538).

É fácil perceber como tal filtro afeta grupos sociais como os trabalhadores, as minorias étnicas e também as mulheres. Qualidades que tendem a ser associadas à fala feminina, como a emotividade, desvalorizam o discurso no interior do campo político. A abertura aos argumentos dos outros, que também faz parte do treinamento social das mulheres, tende a ser interpretada como sinal de deferência (isto é, de subalternidade) ou de hesitação. Mesmo o tom de voz mais agudo é recebido com menos respeito pela audiência ${ }^{2}$. A inclusão efetiva de novos atores - isto é, de novas perspectivas sociais - no campo político significa, portanto, o reconhecimento de outras formas de expressão e comportamento, implicando na remoldagem dos filtros de ingresso e do habitus dominante no próprio campo.

A pesquisa, assim, articula os conceitos de campo e de perspectiva. Enquanto o primeiro enfatiza a homogeneização do comportamento dos agentes, na medida em que o campo impõe seu habitus próprio àqueles que nele desejam ingressar, o segundo indica uma pluralidade de perspectivas, que refletem as vivências diferenciadas que as estruturas sociais proporcionam aos integrantes dos diversos grupos presentes na sociedade. As demandas por reconhecimento e por presença exigem, para se tornarem efetivas, a reconfiguração do campo político. A 
1 Cidades (Brasil) - trânsito, transporte coletivo, direito do consumidor, greves em serviços públicos (exceto educação e saúde; ver categorias 6 e 24 ) etc.

2 Ciência/tecnologia - novidades científicas, médicas e tecnológicas

3 Desastres - catástrofes naturais, acidentes de trânsito e ferroviários, desastres aéreos etc.

4 Ecologia/meio-ambiente - espécies ameaçadas, áreas de preservação etc.

5 Economia brasileira - inflação, desemprego, câmbio, dívida pública, balança comercial e de pagamentos, reajustes salariais etc. - todas as reportagens que envolvem decisões de política econômica são consideradas "Política brasileira" (ver categorias 12 a 22)

6 Educação - vagas no ensino público, vestibular, ação afirmativa e outras formas de acesso ao ensino superior, distribuição de material didático, experiências inovadoras na educação no Brasil, greves de professores etc.

7 Esportes

8 Fait divers/variedades - curiosidades, anúncios de programas da própria emissora, fofocas sobre celebridades, eventos da indústria cultural, "mundo animal" etc. - não inclui "lições de vida" (ver categoria 10)

9 Internacional - política externa brasileira, relações exteriores, política interna de outros países etc.

10 Lições de vida - abordagem "edificante", mostrando como indivíduos e/ou grupos superam suas dificuldades

11 Polícia - crimes, busca de criminosos, revoltas de presidiários etc. - não inclui políticas públicas de segurança (ver categoria

12 Política brasileira: ações do poder executivo federal

13 Política brasileira: propostas legislativas e ações no Congresso - ações do e no Congresso; inclui o debate e tramitação de toda e qualquer proposta legislativa, inclusive quando de iniciativa do poder executivo

14 Política brasileira: judiciário - decisões judiciais, em especial das cortes superiores, com repercussão política - inclui também ações de orgãos com ação de tipo judicial que pertencem ao poder legislativo (Tribunal de Contas) ou ao poder executivo (Ministério Público)

15 Política brasileira: escândalos - denúncias e investigações de atos ilícitos, improbidades e desvios de conduta em geral, envolvendo governantes, parlamentares, líderes partidários e ocupantes dos primeiros escalões das administrações municipais, estaduais e federal

16 Política brasileira: eleições (resultado de pesquisas) - toda e qualquer divulgação de sondagens de intenções de voto, bem como de resultados eleitorais

17 Política brasileira: eleições (curiosidades/serviço) - informações aos eleitores (como usar a urna, como justificar ausência etc.) e curiosidades à margem do processo eleitoral (trabalho dos TREs nas fronteiras do país, eleitores idosos ou jovens etc.)

18 Política brasileira: eleições (debate eleitoral) - falas dos candidatos e de outros líderes políticos, programas de governo, eventos de campanha (passeatas, comícios etc.), denúncias contra candidatos

19 Política brasileira: vida partidária - conflitos internos de partidos, escolha de líderes etc.

20 Política brasileira: movimentos sociais/sociedade civil - ação de movimentos sociais ou de entidades da sociedade civil

21 Política brasileira: história/curiosidades - lembrança de episódios passados da política nacional, motivadas por efemérides (e.g., 50 anos do suicídio de Vargas) ou falecimentos (e.g., a biografia de Leonel Brizola); curiosidades da política nacional

22 Política brasileira: outros/mix - reportagens de política brasileira que mesclam várias das categorias anteriores, sem que seja possível indicar uma predominância - atenção: usar apenas em último caso

23 Previsão do tempo

24 Saúde pública - epidemias, saneamento, controle de medicamentos, rede hospitalar, greves de profissionais da saúde etc.

25 Segurança pública - políticas de segurança pública

26 Outros - usar apenas em último caso (e, de preferência, não usar)

mídia é parte fundamental do processo, dada sua condição de um dos principais vetores do capital político nas sociedades contemporâneas.

\section{Metodologia}

Foi realizado o acompanhamento do noticiário político em três períodos diferentes, de três meses cada um, nos primeiros e segundo semestre de 2006 e no primeiro semestre de $2007^{3}$. Em vista da realização das eleições gerais de outubro de 2006, os períodos serão denominados como "período pré-eleitoral", "período eleitoral" e "período pós-eleitoral". O fato de serem períodos diferentes contribui para equilibrar a amostra, compensando o peso que um evento específico, como as próprias eleições, pode ter na cobertura da mídia. Por outro lado, o fato de serem períodos diferentes, em vez de uma amostra de edições esparsas, permite o acompanhamento de determinadas questões e a construção discursiva associada a elas, o que corresponde a etapas posteriores do esforço de pesquisa.

Foram acompanhados três telejornais noturnos - o Jornal Nacional, da Rede Globo, o Jornal da Record, da Rede Record, e o Jornal do SBT, do Sistema Brasileiro de Televisão ${ }^{4}$ - e três revistas semanais de informação Veja, Época e CartaCapital. Neste paper, os dados das revistas analisadas referem-se aos três períodos mencionados e os dos telejornais, a um deles (o período eleitoral).

Após um mapeamento de todo o noticiário, por meio de uma ficha de leitura (para cada reportagem, coluna ou artigo foi preenchida uma ficha) que orientava a 
Luis Felipe Miguel e Flávia Biroli • 24-39

\begin{tabular}{lcccc} 
& Veja & Epoca & $\begin{array}{c}\text { Carta } \\
\text { Capital }\end{array}$ & total \\
\hline reportagem & $51,4 \%$ & $45,5 \%$ & $28,0 \%$ & $41,7 \%$ \\
\hline entrevista & $6,3 \%$ & $7,5 \%$ & $4,2 \%$ & $5,8 \%$ \\
\hline coluna & $26,9 \%$ & $30,8 \%$ & $24,9 \%$ & $27,2 \%$ \\
\hline editorial & $2,6 \%$ & $2,9 \%$ & $12,4 \%$ & $6,1 \%$ \\
\hline charge & - & $0,2 \%$ & $0,1 \%$ & $0,1 \%$ \\
\hline artigo & $0,6 \%$ & $0,4 \%$ & $9,9 \%$ & $3,8 \%$ \\
\hline nota & $3,2 \%$ & - & $9,2 \%$ & $4,5 \%$ \\
\hline critica & $4,3 \%$ & $6,8 \%$ & $3,2 \%$ & $4,6 \%$ \\
\hline "box" & $4,7 \%$ & $5,9 \%$ & $8,2 \%$ & $6,2 \%$ \\
\hline total & $100 \%$ & $100 \%$ & $100 \%$ & $100 \%$ \\
\hline
\end{tabular}

\begin{tabular}{|c|c|c|c|c|}
\hline & Veja & Epoca & $\begin{array}{l}\text { Carta } \\
\text { Capital }\end{array}$ & total \\
\hline Cidades (Brasil) & $1,5 \%$ & $4,1 \%$ & $3,4 \%$ & $28 \%$ \\
\hline Ciência / tecnologia & $68 \%$ & $10,9 \%$ & $4,6 \%$ & $70 \%$ \\
\hline Desastres & $0,6 \%$ & $17 \%$ & $0,3 \%$ & $0,8 \%$ \\
\hline Ecologia/meio-ambierte & $1,2 \%$ & $2,2 \%$ & $0,2 \%$ & $1,1 \%$ \\
\hline Economia brasileira & $4,4 \%$ & $4,3 \%$ & $15,4 \%$ & $8,2 \%$ \\
\hline Educação & $1,6 \%$ & $1,3 \%$ & $0,9 \%$ & $1,3 \%$ \\
\hline Esportes & $2,2 \%$ & $1,1 \%$ & $27 \%$ & $2,1 \%$ \\
\hline Fait-divers/variedades & $29,5 \%$ & $26,6 \%$ & $32,5 \%$ & $29,9 \%$ \\
\hline Intemacional & $79 \%$ & $8,5 \%$ & $13,0 \%$ & $98 \%$ \\
\hline Lições de vida & $2,2 \%$ & $30 \%$ & $07 \%$ & $1,9 \%$ \\
\hline Policia & $1,3 \%$ & $1,4 \%$ & $1,2 \%$ & $1,3 \%$ \\
\hline $\begin{array}{l}\text { Política brasileira: } \\
\text { executivo }\end{array}$ & $1,9 \%$ & $4,2 \%$ & $17 \%$ & $2,4 \%$ \\
\hline $\begin{array}{l}\text { Política brasileira: } \\
\text { legislativo }\end{array}$ & $0,8 \%$ & $0,5 \%$ & $0,5 \%$ & $0,6 \%$ \\
\hline $\begin{array}{l}\text { Política brasileira: } \\
\text { judiciărio }\end{array}$ & $0,6 \%$ & $0,3 \%$ & $0,6 \%$ & $0,5 \%$ \\
\hline $\begin{array}{l}\text { Política brasileira: } \\
\text { escândalos }\end{array}$ & $9,2 \%$ & $1,9 \%$ & $38 \%$ & $5,5 \%$ \\
\hline Eleições (pesquisas) & $0,9 \%$ & $0,3 \%$ & $1,1 \%$ & $0,8 \%$ \\
\hline $\begin{array}{l}\text { Eleiģões } \\
\text { (curiosidades/serviço) }\end{array}$ & $17 \%$ & $16 \%$ & $2,6 \%$ & $2,0 \%$ \\
\hline Eleiçöes (deba te eleitoral) & $1,8 \%$ & $4,9 \%$ & $17 \%$ & $2,5 \%$ \\
\hline $\begin{array}{l}\text { Política brasileira: vida } \\
\text { partidária }\end{array}$ & $0,4 \%$ & $0,5 \%$ & $17 \%$ & $0,9 \%$ \\
\hline $\begin{array}{l}\text { Política brasileira: } \\
\text { sociedade civil }\end{array}$ & $0,3 \%$ & $0,4 \%$ & $0,2 \%$ & $0,3 \%$ \\
\hline $\begin{array}{l}\text { Política brasileira: } \\
\text { história }\end{array}$ & $0,3 \%$ & $0,3 \%$ & $0,7 \%$ & $0,4 \%$ \\
\hline $\begin{array}{l}\text { Politica brasileira: } \\
\text { outros/mix }\end{array}$ & $6,8 \%$ & $4,4 \%$ & $2,2 \%$ & $4,6 \%$ \\
\hline Saúde püblica & $1,5 \%$ & $1,0 \%$ & $1,1 \%$ & $1,2 \%$ \\
\hline Segurança pública & $1,9 \%$ & $2,0 \%$ & $1,4 \%$ & $1,8 \%$ \\
\hline Outros & $12,7 \%$ & $12,4 \%$ & $5,9 \%$ & $10,3 \%$ \\
\hline total & $\begin{array}{c}100 \% \\
n=1582\end{array}$ & $\begin{array}{l}100 \% \\
n=981\end{array}$ & $\begin{array}{c}100 \% \\
n=1386\end{array}$ & $\begin{array}{c}100 \% \\
n=3050\end{array}$ \\
\hline
\end{tabular}

associação a categorias temáticas e quantificava a presença de homens e mulheres, entre outros pontos, o noticiário político foi separado e, neste caso, foi preenchida uma ficha para cada personagem. O material jornalístico foi classificado em 26 categorias temáticas, sendo que 12 delas se referiam ao noticiário político (ver quadro 1). Inseridos no software de tratamento estatístico e análise lexical Sphinx Lexica, os dados permitem observar a freqüência da aparição de personagens masculinas e femininas e sua associação com temáticas específicas, bem como efetuar comparações entre os diferentes tipos de veículos (TV e revista), os diferentes órgãos e os diferentes períodos. A análise procurou combinar: (1) análise quantitativa, buscando as regularidades estatísticas que permitam vincular sexo, áreas temáticas de visibilidade midiática, atuação política e acumulação de capital político, e (2) análise do discurso da mídia, que começa a ser feita no início do próximo semestre, procurando tanto identificar os diferentes discursos que se chocam sobre a posição da mulher na política quanto os padrões e regularidades presentes na construção da imagem de mulheres e homens.

\section{Análise dos dados: revistas}

Entre reportagens, entrevistas, colunas, editoriais, charges, artigos, notas, críticas (literárias, musicais etc.) e "boxes" publicados nas revistas semanais analisadas nos três períodos trabalhados, foram preenchidas 3950 fichas de matérias. Na tabela 1, pode-se observar a distribuição dos diferentes tipos de texto, por revista. É notável a maior concentração dos textos da revista Carta Capital em editoriais e artigos de opinião, em relação a Veja e Época, que têm uma maior concentração no gênero reportagem (o que não significa, necessariamente, uma menor "editorialização" do conteúdo noticiado, como poderão indicar as análises discursivas do material).

Se considerarmos o espaço ocupado por cada uma

Tabela 2: Distribuição das páginas das revistas por categorias temáticas

das categorias nas revistas ${ }^{5}$, observamos que "política brasileira", somadas todas as suas subcategorias, ocupa 20,6\% dele - abaixo apenas de "variedades" (tabela 2). Nesse aspecto, há pouca diferença entre as três publicações: Veja concede um pouco mais de espaço à política $(24,6 \%)$, enquanto as outras revistas concedem um pouco menos (Época, 19,3\%; CartaCapital, 16,8\%). Como es- 


\begin{tabular}{|c|c|c|c|c|}
\hline & Veja & Época & $\begin{array}{l}\text { Carta } \\
\text { Capltal }\end{array}$ & total \\
\hline Cidades (Brasil) & $0,5 \%$ & $2,8 \%$ & $2,4 \%$ & $1,9 \%$ \\
\hline Ciência/tecnologia & $92 \%$ & $11,3 \%$ & $3,5 \%$ & $8,4 \%$ \\
\hline Desastres & $07 \%$ & $2,2 \%$ & $0,4 \%$ & $1,2 \%$ \\
\hline Ecologin/meio-ambierte & $07 \%$ & $1,9 \%$ & - & $1,0 \%$ \\
\hline Economia brasileira & $45 \%$ & $3,3 \%$ & $14,0 \%$ & $67 \%$ \\
\hline Educação & $0,4 \%$ & $0,3 \%$ & $07 \%$ & $0,4 \%$ \\
\hline Esportes & $25 \%$ & $1,3 \%$ & $28 \%$ & $2,1 \%$ \\
\hline Fait-divers/variedades & $26,1 \%$ & $28,5 \%$ & $29,5 \%$ & $28,0 \%$ \\
\hline Intemacional & $78 \%$ & $7,2 \%$ & $13,6 \%$ & $9,2 \%$ \\
\hline Lições de vida & $2,2 \%$ & $3,1 \%$ & $0,4 \%$ & $2,1 \%$ \\
\hline Polícia & $0,4 \%$ & $0,8 \%$ & - & $0,4 \%$ \\
\hline Política brasileira & $27,4 \%$ & $24,1 \%$ & $27,8 \%$ & $26,2 \%$ \\
\hline Sainde püblica & $0,9 \%$ & $1,1 \%$ & $1,1 \%$ & $10 \%$ \\
\hline Seguranç püblica & $1,1 \%$ & $1,4 \%$ & $07 \%$ & $1,1 \%$ \\
\hline Uutros & $15,7 \%$ & $10,8 \%$ & $3,1 \%$ & $10,3 \%$ \\
\hline total & $\begin{array}{l}1 W \% \\
n=5555\end{array}$ & $\begin{array}{l}1 W \% \\
n=639\end{array}$ & $\begin{array}{l}1 \omega \% \\
n=457\end{array}$ & $\begin{array}{c}1 W \% \\
n=1651\end{array}$ \\
\hline
\end{tabular}

Tabela 03: Espaço concedido por subcategoria, no noticiário político das revistas de informação (comparação entre o período eleitoral e a base de dados geral)

perado, CartaCapital mostra um perfil diferenciado de suas concorrentes, dedicando espaço consideravelmente maior à economia e ao noticiário internacional, e menor a ciência e tecnologia. Entre as subcategorias da política brasileira, é notável a concentração maior de Veja em "escândalos" e de Época no debate eleitoral e nas ações do poder executivo. Vale observar que, entre as revistas, a maior cobertura ao poder executivo (Época dedica o dobro do espaço das outras revistas ao tema) correspondeu à menor cobertura aos escândalos (nesse caso, Epoca dedicou um espaço quase cinco vezes menor que o de Veja e duas vezes menor que o de CartaCapital).

Quando se analisa apenas o período eleitoral, o espaço ocupado pelas subcategorias "política brasileira" continua a ser o segundo maior $(26,2 \%)$, ultrapassado, novamente, apenas pela categoria "variedades" $(27,9 \%)$. As três revistas passam a dedicar mais espaço ao noticiário político, mas CartaCapitalé, dessa vez, a revista que dedica maior espaço. Nela, há um crescimento superior a 10 pontos percentuais no espaço concedido ao noticiário político, se comparado o período eleitoral com o universo total da pesquisa - obtido às custas, sobretudo, do noticiário sobre cidades, sobre ciência e tecnologia, sobre segurança pública e econômico, os que mais recuaram.

Na tabela 4, abaixo, pode-se comparar o noticiário político nas três revistas no período eleitoral, apenas, e no universo dos três períodos que a pesquisa abrange. No período eleitoral, a concentração da cobertura de Veja aos escândalos permanece, apesar de um pouco mais baixa. Cresce a cobertura às categorias diretamente ligadas às eleições e diminui consideravelmente a cobertura ao poder executivo em Veja (passando de 1,9\% para 0,5\% do espaço do noticiário) e em Carta Capital (de 1,6\% para 1,3\%), ao contrário de Época - também no período eleitoral a revista dedica o maior espaço à cobertura do poder executivo e o menor espaço aos escândalos.

É interessante observar, ainda, que o aumento da cobertura às eleições não é acompanhado por um aumento da cobertura aos partidos políticos, como mostra a diminuição das inserções na categoria "vida partidária", com exceção de Carta Capital. A subcategoria "sociedade civil" recebe pouca cobertura em todo o material analisado, o que se acentua no período eleitoral, quando não ocupa qualquer espaço no noticiário de Veja e quase nenhum em Carta Capital.

Em todo o período analisado, as vozes identificadas com o governo Lula tiveram uma presença mais de quatro vezes maior do que as vozes de oposição, mas o predomínio foi, de fato, o das matérias que apresentaram "os dois lados", confirmando um procedimento do jornalismo em defesa de sua confiabilidade (tabela 5). É importante lembrar que isso não significa um equilíbrio em termos das perspectivas que predominam nas matérias, havendo a necessidade de uma análise discursiva mais detida para que se possa tecer comentários nesse sentido. Uma vez que o texto das revistas de informação brasileiras tende a ser muito engajado, é possível que a presença freqüente de personagens vinculadas a uma determinada posição não indique adesão, sendo marcada por signos de reprovação ou ironia.

Vale ressaltar a maior concentração de matérias que apresentam apenas vozes governistas na revista Veja, reconhecidamente um veículo hostil à administração Lula e ao Partido dos Trabalhadores. Observando somente a categoria "escândalos", essa revista apresenta um percentual acentuadamente maior de matérias em que há apenas vozes governistas $(38,5 \%)$ do que de matérias em que há apenas vozes oposicionistas $(4,6 \%)$, apresentando ambas as posições em $40 \%$ das matérias analisadas. Quando se passa às subcategorias relacionadas às eleições (somadas), no entanto, a revista apresenta ambas as posições em $77,4 \%$ das matérias, enquanto $8,1 \%$ trazem apenas vozes da oposição e $4,8 \%$ apenas vozes governistas. Essas tendências se mantêm, na mesma revista, quando se trabalha apenas com o período eleitoral. Na categoria escândalos, acentua-se o predomínio das vozes governistas, com $51 \%$ das matérias (contra $4,1 \%$ de vozes oposicionistas e $12,2 \%$ de ambas as 


\begin{tabular}{|c|c|c|c|c|c|c|c|c|}
\hline & \multicolumn{2}{|c|}{ Veja } & \multicolumn{2}{|c|}{ Época } & \multicolumn{2}{|c|}{ CartaCapital } & \multicolumn{2}{|c|}{ to dos } \\
\hline & eleições & geral & eleições & geral & eleições & geral & eleições & geral \\
\hline Executivo & $2,0 \%$ & $7,7 \%$ & $24,0 \%$ & $21,6 \%$ & $4,7 \%$ & $9,9 \%$ & $20,3 \%$ & $11,6 \%$ \\
\hline Legislativo & $2,6 \%$ & $3,3 \%$ & $0,6 \%$ & $2,6 \%$ & $1,6 \%$ & $3,0 \%$ & $6,7 \%$ & $3,1 \%$ \\
\hline Judiciărio & $0,7 \%$ & $2,3 \%$ & $1,9 \%$ & $1,6 \%$ & $2,4 \%$ & $3,4 \%$ & $15,2 \%$ & $2,5 \%$ \\
\hline Escândalos & $32,2 \%$ & $37,4 \%$ & $9,7 \%$ & $10,0 \%$ & $18,9 \%$ & $22,7 \%$ & $19,9 \%$ & $26,8 \%$ \\
\hline Eleições (pesquisas) & $8,6 \%$ & $3,6 \%$ & $1,9 \%$ & $1,6 \%$ & $10,2 \%$ & $6,4 \%$ & $2,5 \%$ & $3,9 \%$ \\
\hline Eleições (curiosidades) & $9,9 \%$ & $6,9 \%$ & $10,4 \%$ & $8,4 \%$ & $27,6 \%$ & $15,5 \%$ & $1,2 \%$ & $9,7 \%$ \\
\hline Eleições (debate eleitoral) & $15,1 \%$ & $7,2 \%$ & $29,9 \%$ & $25,3 \%$ & $13,4 \%$ & $9,9 \%$ & $1,4 \%$ & $12,2 \%$ \\
\hline Vida partidăria & - & $1,8 \%$ & $1,3 \%$ & $2,6 \%$ & $7,1 \%$ & $10,3 \%$ & $18,9 \%$ & $4,4 \%$ \\
\hline Sociedade civil & - & $1,3 \%$ & $2,6 \%$ & $2,1 \%$ & $0,8 \%$ & $1,3 \%$ & $20,3 \%$ & $1,5 \%$ \\
\hline História & $0,7 \%$ & $1,0 \%$ & $0,6 \%$ & $1,6 \%$ & $3,1 \%$ & $4,3 \%$ & $6,7 \%$ & $2,1 \%$ \\
\hline Outros/mix & $28,3 \%$ & $27,4 \%$ & $16,9 \%$ & $22,6 \%$ & $10,2 \%$ & $13,3 \%$ & $15,2 \%$ & $22,3 \%$ \\
\hline Total & $\begin{array}{c}100 \% \\
\pi=152\end{array}$ & $\begin{array}{c}100 \% \\
H=390\end{array}$ & $\begin{array}{c}100 \% \\
\pi=154\end{array}$ & $\begin{array}{c}100 \% \\
t=190\end{array}$ & $\begin{array}{c}100 \% \\
\pi=127\end{array}$ & $\begin{array}{c}100 \% \\
\pi=233\end{array}$ & $\begin{array}{c}100 \% \\
\pi=433\end{array}$ & $\begin{array}{l}100 \% \\
t=813\end{array}$ \\
\hline
\end{tabular}

Tabela 4: Espaço concedido por subcategoria, no noticiário político das revistas de informação (comparação entre o período eleitoral e a base de dados geral)

\begin{tabular}{lcccc} 
& Veja & Epoca & $\begin{array}{c}\text { Carta } \\
\text { Capital }\end{array}$ & total \\
\hline só govemo & & & $97 \%$ & $19.3 \%$ \\
\hline só oposizäo & $5,1 \%$ & $3,1 \%$ & $8,3 \%$ & $5,5 \%$ \\
\hline ambas & $46,4 \%$ & $64,4 \%$ & $45,8 \%$ & $52.2 \%$ \\
nenhuma & $19,6 \%$ & $13,1 \%$ & $36,1 \%$ & $22.9 \%$ \\
\hline total & $100 \%$ & $100 \%$ & $100 \%$ & $100 \%$ \\
\hline & $n=390$ & $n=190$ & $n=233$ & $n=813$ \\
\hline
\end{tabular}

Tabela 5: Posição das

personagens quanto ao governo

federal, nas matérias de política

das revistas

vozes). Nas subcategorias relacionadas às eleições, temos, então, ambas as posições em $66,7 \%$ das matérias, apenas oposição em 7,8\% delas e 5,9\% das matérias com apenas vozes governistas.

Já CartaCapital sinaliza, com sua alta concentração de matérias em que tanto governo quanto oposição estão

\begin{tabular}{|c|c|c|c|c|}
\hline & Veja & Epoca & $\begin{array}{l}\text { Canta } \\
\text { Capital }\end{array}$ & total \\
\hline movimento social & $1,1 \%$ & $17 \%$ & $3,1 \%$ & $2,0 \%$ \\
\hline ONG & $1,3 \%$ & $48 \%$ & $36 \%$ & $3,0 \%$ \\
\hline $\begin{array}{l}\text { organizaç̃o } \\
\text { intemacional }\end{array}$ & $0,9 \%$ & $2,0 \%$ & $27 \%$ & $1,8 \%$ \\
\hline religião organizada & $17 \%$ & $1,1 \%$ & $2,3 \%$ & $1,8 \%$ \\
\hline força ammada & $1,0 \%$ & $16 \%$ & $3,1 \%$ & $1,9 \%$ \\
\hline empresa privada & $21,3 \%$ & $18,8 \%$ & $22,2 \%$ & $21,0 \%$ \\
\hline universidade & $14.9 \%$ & $17,1 \%$ & $9,5 \%$ & $13,5 \%$ \\
\hline nerthum deles & $57,8 \%$ & $52,9 \%$ & $53,5 \%$ & $55 \%$ \\
\hline total & $\begin{array}{c}100 \% \\
n= \\
15 \%\end{array}$ & $\begin{array}{c}100 \% \\
n= \\
981\end{array}$ & $\begin{array}{c}100 \% \\
n-1326\end{array}$ & $\begin{array}{c}100 \% \\
n= \\
3960\end{array}$ \\
\hline
\end{tabular}

Tabela 6: Presença de personagens vinculadas a diferentes grupos nas matérias das revistas semanais

ausentes, a tentativa de produzir um noticiário capaz de avançar além da disputa política imediata. É o que é sinaliza a alta proporção de artigos e colunas na revista (tabela 1, acima) - é neste material, em que há uma menor incidência de personagens vinculadas ao governo ou à 
Tabela 7: Personagens com citação em mais de 70 matérias de política nas revistas

\begin{tabular}{lc}
\hline Luis Inacio Lula da Silva & 769 \\
\hline Geraldo Alckmin & 329 \\
\hline José Serra & 206 \\
\hline José Dirceu & 187 \\
\hline Fernando Henrique Cardoso & 171 \\
\hline Antonio Palocci & 144 \\
\hline Aécio Neves & 115 \\
\hline Tarso Genro & 84 \\
\hline anônimos & 82 \\
\hline Marcos Valério & 79 \\
\hline Aldo Rebelo & 78 \\
\hline Ciro Gomes & 78 \\
\hline
\end{tabular}

\begin{tabular}{|c|c|c|c|}
\hline & mulleres & homens & total \\
\hline poder executivo & $6,9 \%$ & $93,1 \%$ & $\begin{array}{c}100 \%(n= \\
243)\end{array}$ \\
\hline poder legislativo & $86 \%$ & $91,4 \%$ & $\begin{array}{c}100 \%(n= \\
2311)\end{array}$ \\
\hline poder judiciúrio & $12,7 \%$ & $87,3 \%$ & $100 \%(n=268)$ \\
\hline competência técrica & $9,9 \%$ & $90,1 \%$ & $\begin{array}{c}100 \%(n= \\
1239)\end{array}$ \\
\hline "popular" & $37,8 \%$ & $62,2 \%$ & $100 \%(n=209)$ \\
\hline
\end{tabular}

Tabela 8: Distribuição das personagens das diferentes competências específicas, por sexo, no noticiário político das revistas

oposição, que o jornalismo busca transcender o registro factual.

A esmagadora maioria das personagens presentes no noticiário político integra o campo político em sentido estrito. Entre as que não se incluem nele, o grupo presente com maior peso, especialmente em comparação com os demais, é o empresariado. As personagens vinculadas a empresas privadas somam 7,7\% das inserções; em segundo lugar vêm as universidades, com 2,6\%. Movimentos sociais, ONGs, organismos internacionais, grupos religiosos e forças armadas somam 2,8\% das inserções.

Mesmo nas revistas como um todo - incluindo todas as categorias de matérias, não apenas as de política brasileira - a presença destes grupos é pequena. Em mais de $60 \%$ das matérias, eles estão integralmente ausentes (tabela 6). Com exceção das ONGs, mais presentes em Época, e das universidades, todos os grupos apa-

\begin{tabular}{lccc} 
& mulher & homem & Total \\
\hline movimento social & $7,8 \%$ & $92,2 \%$ & $100 \%(n=77)$ \\
ONG & $12,6 \%$ & $87,4 \%$ & $\begin{array}{c}100 \%(\mathrm{n} \\
=103)\end{array}$ \\
\hline $\begin{array}{l}\text { organismo } \\
\text { internaciona1 }\end{array}$ & $19,6 \%$ & $80,4 \%$ & $100 \%(n=46)$ \\
religião & $8,9 \%$ & $91,1 \%$ & $100 \%(n=90)$ \\
organizada & - & $100 \%$ & $100 \%(n=40)$ \\
força armada & $9,7 \%$ & $90,3 \%$ & $\begin{array}{c}100 \%(\mathrm{n} \\
=1010)\end{array}$ \\
\hline $\begin{array}{l}\text { empresa privada } \\
\text { universidade }\end{array}$ & $11,9 \%$ & $88,1 \%$ & $\begin{array}{c}100 \%(\mathrm{n} \\
=336)\end{array}$ \\
\hline & $10,1 \%$ & $89,9 \%$ & $\begin{array}{c}100 \%(\mathrm{n}= \\
1702)\end{array}$ \\
\hline
\end{tabular}

Tabela 9: Personagens do noticiário político das revistas, por grupo e sexo

\begin{tabular}{lccc}
\hline & mulleres & homens & Total \\
\hline presidente & $6,9 \%$ & $93,1 \%$ & $100 \%(n=1073)$ \\
govemador & $12,7 \%$ & $87,3 \%$ & $100 \%(n=622)$ \\
\hline senador & $70 \%$ & $93,0 \%$ & $100 \%(n=142)$ \\
\hline deputado federal & $5,1 \%$ & $94,9 \%$ & $100 \%(n=355)$ \\
\hline deputado estadual & $19,4 \%$ & $80,6 \%$ & $100 \%(n=36)$ \\
\hline
\end{tabular}

Tabela 10: Distribuição dos candidatos, por sexo, no noticiário político das revistas

recem mais em CartaCapital do que em suas concorrentes.

O noticiário, como um todo, apresentou 32533 personagens, sendo $80,4 \%$ masculinas e $19,6 \%$ femininas $^{6}$. Quando se trata apenas do noticiário político, essa diferença se acentua: de um total de 13001 personagens, $89,9 \%$ são do sexo masculino, contra apenas $10,1 \%$ do sexo feminino.

Entre as personagens mais citadas no noticiário político das revistas, aquelas presentes em 70 ou mais matérias, não há nenhuma mulher (tabela 7). As mulheres presentes com maior freqüência são a senadora e candidata à presidência Heloísa Helena, em 20 lugar, com 66 citações, a candidata, depois ministra, Marta Suplicy, em $25^{\circ}$ lugar, com 61 citações, e a ministra da Casa-Civil, Dilma Rousseff, em $29^{\circ}$ lugar, com 49 citações. A personagem mais citada, entre homens e mulheres, é o presi- 
Luis Felipe Miguel e Flávia Biroli • 24-39

\begin{tabular}{|c|c|c|}
\hline Cidades (Brasil) & 4,30 & $15 \%$ \\
\hline Ciência/tecnologin & $3,5 \%$ & $3,8 \%$ \\
\hline Desastres & $07 \%$ & $0,5 \%$ \\
\hline Ecologia/meio-tmbierte & $0,4 \%$ & $0,4 \%$ \\
\hline Economia brasileira & $1,5 \%$ & $3,9 \%$ \\
\hline Educação & $1,1 \%$ & $0,4 \%$ \\
\hline Esportes & $0,6 \%$ & $2,2 \%$ \\
\hline Fait-divers/variedades & $49,8 \%$ & $31,8 \%$ \\
\hline Intemacional & $4,8 \%$ & $9 \%$ \\
\hline Lições de vila & $2,3 \%$ & $0,9 \%$ \\
\hline Polícia & $1,3 \%$ & $1,2 \%$ \\
\hline $\begin{array}{l}\text { Política brasileira: ações do poder } \\
\text { executivo }\end{array}$ & $0,8 \%$ & $1,9 \%$ \\
\hline $\begin{array}{l}\text { Política brasileira: propostas } \\
\text { legislativas e açóes no legislativo }\end{array}$ & $0,2 \%$ & $07 \%$ \\
\hline Política brasileira: judiciário & $0,3 \%$ & $0,5 \%$ \\
\hline Política brasileira: escândalos & $3,9 \%$ & $97 \%$ \\
\hline $\begin{array}{l}\text { Política brasileira: eleiçóes (resultado } \\
\text { de pesquisas) }\end{array}$ & $0.5 \%$ & $0,8 \%$ \\
\hline $\begin{array}{l}\text { Política brasileira: eleições } \\
\text { (curiosidades/serviço) }\end{array}$ & $1,4 \%$ & $23 \%$ \\
\hline $\begin{array}{l}\text { Política brasileira: eleições (debate } \\
\text { eleitoral) }\end{array}$ & $26 \%$ & $3,4 \%$ \\
\hline Política brasileira: vida partidária & $0,5 \%$ & $1,5 \%$ \\
\hline $\begin{array}{l}\text { Politica brasileira: movimentos } \\
\text { sociais / sociedade civil }\end{array}$ & - & $0,3 \%$ \\
\hline Política brasileira: história & $0,1 \%$ & $0,6 \%$ \\
\hline Política brasileira: outros/mix & $37 \%$ & $6,4 \%$ \\
\hline Saúde pública & $07 \%$ & $0,4 \%$ \\
\hline Segurança pública & $1,2 \%$ & $1,3 \%$ \\
\hline Outros & $12,8 \%$ & $13,4 \%$ \\
\hline total & $\begin{array}{c}100 \% \\
n=6364\end{array}$ & $\begin{array}{c}100 \% \\
n=26169\end{array}$ \\
\hline
\end{tabular}

\begin{tabular}{|c|c|c|}
\hline categoria & mulleres & homens \\
\hline Cidades/cotidiano & $14,15 \%$ & $6,16 \%$ \\
\hline Ciência/tecnologia & $2,11 \%$ & $1,28 \%$ \\
\hline Desastres & $4,06 \%$ & $3,60 \%$ \\
\hline Ecologin/meio-embiente & $1,62 \%$ & $1,87 \%$ \\
\hline Economia brasileira & $5,53 \%$ & $3,05 \%$ \\
\hline Educação & $2,11 \%$ & $0,66 \%$ \\
\hline Esportes & $5,34 \%$ & $13,43 \%$ \\
\hline Fait-divers/variedades & $14,41 \%$ & $5,20 \%$ \\
\hline Intemacional & $9,07 \%$ & $9,50 \%$ \\
\hline Lições de vida & $1,62 \%$ & $0,56 \%$ \\
\hline Policia & $12,57 \%$ & $12,08 \%$ \\
\hline Política brasileira & $22,95 \%$ & $39,80 \%$ \\
\hline Previsão do tempo & $0,41 \%$ & $0,15 \%$ \\
\hline Saúde pública & $2,37 \%$ & $0,86 \%$ \\
\hline Segurança pública & $1,69 \%$ & $179 \%$ \\
\hline total & $\begin{array}{c}100 \% \\
n=2658\end{array}$ & $\begin{array}{c}100 \% \\
n=919\end{array}$ \\
\hline
\end{tabular}

Tabela 12: Distribuição de personagens por categoria de reportagem e sexo, nos telejornais brasileiros

Podemos qualificar, inicialmente, a visibilidade que está vinculada a essa presença de homens e mulheres observando se têm ou não voz nos noticiários (se são apenas citados ou se têm suas palavras direta ou indiretamente compondo o texto) e se têm ou não sua imagem presente em fotos, ilustrações ou caricaturas.

No que diz respeito à possibilidade de ter voz, uma vez presentes no noticiário, homens e mulheres têm uma distribuição semelhante. Cerca de $20 \%$ das personagens existentes no noticiário têm voz direta nos textos - 20,1\% dos homens e $18,9 \%$ das mulheres; cerca de $5 \%$ têm voz indireta nos textos, isto é, têm sua posição citada pelo autor do texto $-4,6 \%$ dos homens e $5,1 \%$ das mulheres. Mas esses percentuais, vale lembrar, seguem os percentuais indicados no parágrafo anterior em relação à presença de homens e mulheres: $90,4 \%$ das personagens que têm voz direta no noticiário político são homens. De maneira correlata, $88,9 \%$ das personagens que têm voz indireta são homens.

Quando se considera o segundo quesito, o da visibilidade ampliada por fotos, ilustrações ou caricaturas, a distribuição de homens e mulheres, de modo geral, acompanha sua presença no noticiário: das personagens que têm suas fotos publicadas na capa das revistas, $72(87,8 \%)$ são homens e $12(11,0 \%)$ são mulheres; das que têm suas fotos publicadas em mais de uma foto interna, 120 (85,7\%) são homens e 20 (14,3\%) são mulheres; em apenas uma foto interna, $2579(90,6 \%)$ são homens e $268(9,4 \%)$ são mulheres. Quando se observa 


\begin{tabular}{|c|c|c|c|c|}
\hline & $\begin{array}{c}\text { Jormal } \\
\text { Nacional }\end{array}$ & Jomal da Band & $\begin{array}{c}\text { SBT } \\
\text { ixasil }\end{array}$ & Total \\
\hline Cidades/cotidiano & $2,6 \%$ & $12,3 \%$ & $7,9 \%$ & $7,4 \%$ \\
\hline Ciência/tecnologia & $1,6 \%$ & $1,8 \%$ & $2,2 \%$ & $1,9 \%$ \\
\hline Desastres & $50 \%$ & $5,2 \%$ & $4,4 \%$ & $4,9 \%$ \\
\hline $\begin{array}{l}\text { Ecologin/meio- } \\
\text { ambiente }\end{array}$ & $2,3 \%$ & $3,9 \%$ & $3,5 \%$ & $3,2 \%$ \\
\hline Economia brasileira & $50 \%$ & $66 \%$ & $4,0 \%$ & $5,2 \%$ \\
\hline Educação & $0,4 \%$ & $0,5 \%$ & $2,0 \%$ & $1,0 \%$ \\
\hline Esportes & $8,5 \%$ & $7,9 \%$ & $57 \%$ & $7,4 \%$ \\
\hline $\begin{array}{l}\text { Fait- } \\
\text { divers/variedades }\end{array}$ & $57 \%$ & $67 \%$ & $67 \%$ & $63 \%$ \\
\hline Intemacional & $13,9 \%$ & $9,5 \%$ & $11,9 \%$ & $11.9 \%$ \\
\hline Lições de vida & $1,2 \%$ & $0,2 \%$ & $1,0 \%$ & $0,8 \%$ \\
\hline Polícia & $10,5 \%$ & $6,9 \%$ & $17,1 \%$ & $11.5 \%$ \\
\hline Política brasileira & $30,5 \%$ & $29,2 \%$ & $25,2 \%$ & $31,5 \%$ \\
\hline Previsão do tempo & $2,0 \%$ & $57 \%$ & $3,5 \%$ & $37 \%$ \\
\hline Saúde pública & $0,9 \%$ & $1,3 \%$ & $2,1 \%$ & $1,4 \%$ \\
\hline Segurança pública & $07 \%$ & $2,3 \%$ & $2,4 \%$ & $1,8 \%$ \\
\hline total & $\begin{array}{c}100 \% \\
n= \\
3821.43\end{array}$ & $\begin{array}{c}100 \% \\
n=34: 0842\end{array}$ & $\begin{array}{c}100 \% \\
n=35: 05: 13\end{array}$ & $\begin{array}{c}100 \% \\
n=107: 35 \cdot 38\end{array}$ \\
\hline
\end{tabular}

percentualmente, quando se trata da voz "popular", não associada a qualquer competência específica.

No que se refere à distribuição por grupos, a tabela 9, abaixo, mostra que a maior presença de mulheres se refere às personagens vinculadas a organismos internacionais, 19,6\%. Nos demais grupos, inclusive movimentos sociais e ONGs, a inserção nas revistas acompanha a média de $10 \%$ da presença no noticiário, reduzindo-se para 7,8\% quando se trata de personagens ligadas a movimentos sociais.

Quando se observa, por fim, os candidatos e candidatas às eleições de 2006 citados no noticiário das revistas, o percentual de mulheres é, em alguns casos, inferior a sua representação atual - o percentual de candidatas à Câmara dos Deputados é de 5,1\% - e, em todos os casos, inferior aos $30 \%$ em que consiste, no Brasil, a reserva de vagas para mulheres entre as candidaturas apresentadas pelos partidos políticos (tabela 10).

Um outro dado relevante diz respeito à distribuição das personagens mulhe-

Tabela 13: Distribuição do tempo dos telejornais, por res e homens pelas diferentes categorias temáticas utilicategorias temáticas (período eleitoral) zadas para a classificação das matérias, já discutidas.

charges, caricaturas ou ilustrações, a distribuição é semelhante: 167 ou $90,8 \%$ são de homens e 17 ou 9,2\% de mulheres.

Pode-se também observar a presença de homens e mulheres no que se refere aos poderes institucionais e às categorias de voz "técnica" (economistas, cientistas sociais, especialistas de modo geral) ou "popular" (muitas vezes meramente ilustrativa de posições presentes nas matérias). A Tabela 8 , abaixo, indica que a concentração da presença de homens relacionados aos três poderes e a uma voz "técnica" acompanha, de modo geral, o percentual da presença de homens e mulheres no noticiário, mas a presença da mulher se amplia,

Tabela 14: Distribuição do tempo das reportagens de política brasileira dos telejornais, por categoria temática (período eleitoral)

\begin{tabular}{|c|c|c|c|c|}
\hline & $\begin{array}{c}\text { Jomal } \\
\text { Nacional }\end{array}$ & Jomal da Band & $\begin{array}{l}\text { SBT } \\
\text { irasil }\end{array}$ & Total \\
\hline $\begin{array}{l}\text { Ações do poder } \\
\text { executivo }\end{array}$ & $0,8 \%$ & $4,1 \%$ & $87 \%$ & $38 \%$ \\
\hline $\begin{array}{l}\text { Propostas } \\
\text { legislativas e ações } \\
\text { no legislativo }\end{array}$ & $3,8 \%$ & $6,2 \%$ & $36 \%$ & $4,4 \%$ \\
\hline Judiciário & $1,5 \%$ & $9,9 \%$ & $2,0 \%$ & $4,1 \%$ \\
\hline Escândalos & $27,6 \%$ & $23,6 \%$ & $25,8 \%$ & $26,0 \%$ \\
\hline $\begin{array}{l}\text { Eleições (resultados } \\
\text { de pesquisas) }\end{array}$ & $10,4 \%$ & $7,9 \%$ & $3,2 \%$ & $7,9 \%$ \\
\hline $\begin{array}{l}\text { Eleições } \\
\text { (curiosidades/servi } \\
\text { ço) }\end{array}$ & $33 \%$ & $3,8 \%$ & $10,3 \%$ & $5,1 \%$ \\
\hline $\begin{array}{l}\text { Eleiçöes (debate } \\
\text { eleitoral) }\end{array}$ & $30,6 \%$ & $33,6 \%$ & $31,3 \%$ & $31,7 \%$ \\
\hline Vida partidária & $18 \%$ & $3,4 \%$ & $8,3 \%$ & $38 \%$ \\
\hline $\begin{array}{l}\text { Movimentos } \\
\text { sociais/sociedade } \\
\text { civil }\end{array}$ & $13 \%$ & $48 \%$ & $1,2 \%$ & $2,2 \%$ \\
\hline História & - & - & $0,4 \%$ & $0,1 \%$ \\
\hline Outros/mix & $19,0 \%$ & $27 \%$ & $5,2 \%$ & $10,8 \%$ \\
\hline Total & $\begin{array}{c}100 \% \\
n=608\end{array}$ & $\begin{array}{c}100 \% \\
n=378\end{array}$ & $\begin{array}{c}100 \% \\
n=356\end{array}$ & $\begin{array}{c}100 \% \\
n=1322\end{array}$ \\
\hline
\end{tabular}


Como se pode observar na tabela 11, a maior concentração das mulheres é na categoria fatos diversos/variedades $(49,8 \%)$. A dos homens segue a mesma tendência, porém em percentual mais reduzido $(31,8 \%)$. As personagens mulheres estão presentes também em percentual consideravelmente maior que o dos homens nas categorias "cidades" ( $4,3 \%$ contra 1,5\%), "lições de vida" (2,3\% contra $0,9 \%)$, categorias que trazem um grande número de personagens "populares", e "educação" $(1,1 \%$ contras $0,4 \%$ ), área que costuma ser, nas divisões de gênero tradicionais, associada ao papel feminino. Em outras categorias, ainda, há uma concentração ligeiramente maior das personagens femininas em relação às masculinas: são "desastres", "polícia" e "saúde pública". Por outro lado, a concentração maior dos homens na categoria "economia" (3,8\% contra 1,5\%), assim como no noticiário político, indica não apenas uma maior presença quantitativa, mas também que eles ocupam posições mais centrais no noticiário, já que há uma hierarquia entre as áreas e campos sociais nas representações da realidade presentes na imprensa.

Quando se observa a concentração no noticiário político, especificamente, vale destacar a ausência de mu heres na categoria "movimentos sociais/sociedade ci-

\begin{tabular}{lccc}
\hline & $\begin{array}{c}\text { Jomial } \\
\text { Nacion } \\
\text { al }\end{array}$ & $\begin{array}{c}\text { Jomalda } \\
\text { Band }\end{array}$ & $\begin{array}{c}\text { SB } \\
\text { basil }\end{array}$ \\
\hline só govemo & $12,5 \%$ & $12,4 \%$ & $13,4 \%$ \\
\hline só oposignão & $36,8 \%$ & $7,4 \%$ & $4,5 \%$ \\
\hline Ambas & $10,5 \%$ & $34,1 \%$ & $41,4 \%$ \\
\hline nenhuma & $37 \%$ & $15,3 \%$ & $12,5 \%$ \\
\hline não se aplica & $36,6 \%$ & $30,7 \%$ & $28,3 \%$ \\
\hline Total & $100 \%$ & $100 \%$ & $100 \%$ \\
& $n=593$ & $n=378$ & $n=336$ \\
\hline
\end{tabular}

Tabela 15: Posição das personagens em relação ao governo federal, nas matérias de política dos telejornais (período eleitoral)

Tabela 16: Personagens com citação em mais de 30 reportagens de política nos telejornais brasileiros (período eleitoral) vil" e a concentração maior das personagens masculinas na categoria "escândalos". Comparando a presença de homens e mulheres nas três categorias relacionadas às eleições, somadas, temos $6,5 \%$ das personagens masculinas contra $4,5 \%$ das femininas. Se, a essas três categorias, somamos a categoria "vida partidária", temos $8 \%$ dos homens contra 5\% das mulheres. Vale lembrar que, em todos os casos, trata-se do percentual em relação ao número total de homens, comparado ao percentual em relação ao número total de mulheres, e, portanto, de um percentual de concentração dentro de uma representação bastante reduzida das mulheres nos noticiários (como se disse antes, 19,6 das personagens citadas em todo o material analisado) e, sobretudo, no noticiário político (como se disse antes, 10,1\% das personagens citadas no noticiário político analisado).

Quando se considera a distribuição de homens e mulheres apenas no período eleitoral, nas três categorias dois casos, o dobro da concentração que se observa no universo dos dados. Se, a essas três categorias, somamos a categoria "vida partidária", temos 14,2\% dos homens contra $10 \%$ das mulheres, com um crescimento levemente maior da concentração das mulheres nessa categoria em relação à concentração dos homens.

\begin{tabular}{|lc|}
\hline nome & $\begin{array}{c}\text { matevias em que foi } \\
\text { citado }\end{array}$ \\
\hline Lula & 372 \\
\hline Geraldo Alchmin & 299 \\
\hline Heloísa Helena & 168 \\
\hline Cristovam Buarque & 155 \\
\hline Luiz Vedoin & 75 \\
\hline Luciano Bivar & 67 \\
\hline José Maria Eymael & 66 \\
\hline José Serra & 48 \\
\hline Ricardo Berzoini & 46 \\
\hline Tarso Gerro & 42 \\
\hline Valdebram Padilha & 42 \\
\hline Ney Suassuna & 40 \\
\hline Gedimar Passos & 37 \\
\hline Valdebram Padilla & 37 \\
\hline Márcio Thomaz Bastos & 39 \\
\hline Femando Herrique Cardoso & 38 \\
\hline Antônio Biscaia & 35 \\
\hline Freud Godoy & 35 \\
\hline Jorge Lorenzetti & 34 \\
\hline RaulJungmann & 33 \\
\hline Tasso Jereissati & 31 \\
\hline Magno Malta & 30 \\
\hline
\end{tabular}


Gênero e políitca no jornalismo brasileiro • $24-39$

\begin{tabular}{|c|c|c|c|c|c|c|c|}
\hline & $\begin{array}{l}\text { apenas citado } \\
\text { porrepórtex }\end{array}$ & $\begin{array}{l}\text { citado por } \\
\text { outro } \\
\text { entreuistado }\end{array}$ & $\begin{array}{l}\text { somid-bite } \\
\text { com posiģấo }\end{array}$ & $\begin{array}{l}\text { sourdbite } \\
\text { com } \\
\text { axgmento }\end{array}$ & $\begin{array}{l}\text { sound-bite } \\
\text { técuico }\end{array}$ & $\begin{array}{l}\text { sound-bite } \\
\text { inelevarte }\end{array}$ & total \\
\hline executivo & $54,0 \%$ & $9,0 \%$ & $10,2 \%$ & $26,2 \%$ & $1,2 \%$ & $2,2 \%$ & $100 \%(n=1127)$ \\
\hline legislativo & $56,5 \%$ & $17 \%$ & $11,6 \%$ & $27,4 \%$ & $1,9 \%$ & $1,4 \%$ & $100 \%(n=1177)$ \\
\hline judiciário & $48,9 \%$ & - & $11,5 \%$ & $28,2 \%$ & $9,9 \%$ & $1,5 \%$ & $100 \%(n=131)$ \\
\hline Técrico & $13,2 \%$ & - & $9,3 \%$ & $20,9 \%$ & $54,3 \%$ & $3,1 \%$ & $100 \%(n=129)$ \\
\hline popular & $53 \%$ & $0,90 \%$ & $17,2 \%$ & $10,0 \%$ & $1,4 \%$ & $66,3 \%$ & $100 \%(n=430)$ \\
\hline nenhum & $68,5 \%$ & $370 \%$ & $5,5 \%$ & $18,8 \%$ & $16 \%$ & $28 \%$ & $100 \%(n=1417)$ \\
\hline Total & $53,3 \%$ & $4,0 \%$ & $9,8 \%$ & $22,5 \%$ & $33 \%$ & $8,4 \%$ & $100 \%(n=4411)$ \\
\hline
\end{tabular}

Tabela 17: Tipo de citação nas matérias de política dos telejornais, por posição institucional das personagens. Obs. Eram possíveis múltiplas respostas, na variável "Tipo de citação".

\section{Análise dos dados: telejornais}

A análise dos telejornais - Jornal Nacional, Jornal da Band e SBT Brasil - compreende o período imediatamente anterior às eleições de 2006. Foram estudadas as edições dos meses de julho a outubro de 2006. Problemas na gravação dos DVDs comprometeram cerca de $10 \%$ do material, seja na forma de edições perdidas, seja na forma de edições incompletas.

Ao todo, foram listadas 12077 "personagens", isto é, pessoas que não pertencem à equipe jornalística e que aparecem falando no noticiário ou são citadas por repórter, apresentador ou outra personagem. Apenas $22 \%$ dessas personagens são do sexo feminino. Divididas as matérias dos telejornais em diferentes categorias, verifica-se que a predominância de personagens do sexo masculino se reflete em todas elas. A distribuição das personagens por categoria de matéria, porém, varia amplamente entre os sexos (tabela 12). "Política brasilei$\mathrm{ra}^{\prime}$ é a categoria mais freqüente para ambos os sexos, mas a concentração é muito mais intensa entre os homens. As mulheres se destacam ainda no noticiário de variedades e sobre o cotidiano, com uma concentração muito maior que os homens, ao passo que os eles aparecem com mais freqüência em esportes e polícia.

Cumpre observar que a tabela 12 apresenta a proporção com que cada categoria aparece entre as personagens de um mesmo sexo. Observados os números absolutos, as mulheres estão em minoria em todas elas. Além disso, existem disparidades na forma como a presença se dá, dentro de cada categoria. Muitas das mulheres presentes em reportagens de economia, por exemplo, são donas-de-casa entrevistadas em enquetes sobre consumo. Nas reportagens policiais, há diferença na presença como vítima, com maior concentração feminina, e como criminoso ou suspeito e investigador. Ainda assim, chama a atenção o fato de que a categoria "política brasileira" é a única em que a concentração dos homens é substancialmente maior que a das mulheres.
Quanto à categoria "cor", em apenas 19,3\% das matérias foi identificada ao menos uma personagem nãobranca. A política brasileira ficou abaixo da média geral, com $9,8 \%$ das inserções incluindo personagem não-branca. Elas aparecem com mais freqüência nas matérias sobre "lições de vida" (70,4\%), educação (50\%) e esportes $(42,8 \%)$.

Entre reportagens, notas, entrevistas, comentários e um único editorial, foram identificadas 1307 inserções relacionadas à temática "política brasileira", com uma nítida predominância do Jornal Nacional (593 inserções), seguido de Jornal da Band (378) e SBT Brasil (336). Cada uma delas durou, em média 93,8 segundos, sem diferença significativa entre os três telejornais, o que é um tempo alto para os padrões da televisão brasileira - mas a média foi inflada pela presença de mais de uma dúzia de entrevistas de estúdio com candidatos e grandes reportagens, com mais de 10 minutos de duração cada. As reportagens sobre política brasileira (reunindo as 12 subcategorias) ocuparam a maior parte do noticiário em todos os três telejornais (tabela 13).

Como o esperado, a movimentação em torno das eleições ocupou a maior parte do noticiário político, ficando com $44,8 \%$ das inserções (somadas as três subcategorias relacionadas ao tema). Aí, no entanto, existem diferenças perceptíveis entre os telejornais, conforme indica a tabela 14.

A voz da oposição se fez ligeiramente mais freqüente no noticiário do que o governo federal - mas é o Jornal Nacional que leva a esse resultado, como mostra a tabela 15. No Jornal da Band e no SBT Brasil, em geral cada reportagem apresenta "os dois lados"; quando há apenas uma posição, é mais freqüente que seja governista. $\mathrm{O}$ noticioso da Rede Globo, porém, na maioria de suas inserções de política, deu voz apenas à oposição.

No entanto, mais de $95 \%$ das inserções do Jornal Nacional em que aparece apenas a oposição se referem à categoria "debate eleitoral". O aparente predomínio de uma posição contrário ao governo é, assim, mero efeito da prática do telejornal de apresentar a agenda dos candidatos em uma série de pequenas matérias separadas - cada uma dela contando como uma inserção e sendo todos os candidatos, à exceção de Lula, classificados como "oposição". 
Luis Felipe Miguel e Flávia Biroli • 24-39

\begin{tabular}{|c|c|c|c|}
\hline $\begin{array}{l}\text { apenas citado(a) por } \\
\text { reporter }\end{array}$ & $38,31 \%$ & 55,8010 & $53,31 \%$ \\
\hline $\begin{array}{l}\text { citado(a) por outro(a) } \\
\text { entrevistado(a) }\end{array}$ & $2,0 \%$ & $4,4 \%$ & $4,0 \%$ \\
\hline sound-bite com posição & $12,7 \%$ & $9,3 \%$ & $9,8 \%$ \\
\hline $\begin{array}{l}\text { sound-bite com } \\
\text { argumento }\end{array}$ & $21,7 \%$ & $22,6 \%$ & $22,5 \%$ \\
\hline $\begin{array}{l}\text { sound-bite técruico- } \\
\text { descritivo }\end{array}$ & $25 \%$ & $3,4 \%$ & $3,3 \%$ \\
\hline sound-bite irrelevante & $23,3 \%$ & $5,9 \%$ & $8,4 \%$ \\
\hline total & $\begin{array}{c}100 \% \\
n=640\end{array}$ & $\begin{array}{c}100 \% \\
n=3771\end{array}$ & $\begin{array}{c}100 \% \\
n=4411\end{array}$ \\
\hline
\end{tabular}

Tabela 18: Distribuição das personagens por sexo e tipo de citação nas matérias de política dos telejornais (período eleitoral) Obs. Eram possíveis múltiplas respostas, na variável "Tipo de citação".

\begin{tabular}{lccc} 
& mulleres & homens & total \\
\hline Executivo & $12,2 \%$ & $27,8 \%$ & $25,5 \%$ \\
Legislativo & $31,4 \%$ & $25,9 \%$ & $26,7 \%$ \\
\hline Judiciário & $1,3 \%$ & $3,3 \%$ & $3,0 \%$ \\
Técrico & $3,8 \%$ & $2,8 \%$ & $2,9 \%$ \\
Popular & $29,5 \%$ & $6,4 \%$ & $97 \%$ \\
Nenhum & $21,9 \%$ & $33,9 \%$ & $32,1 \%$ \\
\hline Total & $100 \%$ & $100 \%$ & $100 \%$ \\
& $n=640$ & $n=3771$ & $n=1411$ \\
\hline
\end{tabular}

Tabela 19: Distribuição das personagens por sexo e posição institucional de citação nas reportagens de política dos telejornais (período eleitoral)

\begin{tabular}{|c|c|c|c|}
\hline & mulheres & homens & total \\
\hline $\begin{array}{l}\text { aperas citado(a) por } \\
\text { repórter }\end{array}$ & $53,0 \%$ & $59,1 \%$ & $58,4 \%$ \\
\hline $\begin{array}{l}\text { citado(a) por outro(a) } \\
\text { entrevistado(a) }\end{array}$ & $2,4 \%$ & $4,6 \%$ & $4,4 \%$ \\
\hline sound-bite com posição & $10,9 \%$ & $87 \%$ & $90 \%$ \\
\hline $\begin{array}{l}\text { sound-bite com } \\
\text { argumento }\end{array}$ & $27,1 \%$ & $23,4 \%$ & $23,8 \%$ \\
\hline $\begin{array}{l}\text { sound-bite técrnico- } \\
\text { descritivo }\end{array}$ & $2,9 \%$ & $36 \%$ & $35 \%$ \\
\hline sound-bite irrelevante & $4,4 \%$ & $1,9 \%$ & $22 \%$ \\
\hline total & $\begin{array}{c}100 \% \\
n=451\end{array}$ & $\begin{array}{c}100 \% \\
n=3530\end{array}$ & $\begin{array}{c}100 \% \\
n=3981\end{array}$ \\
\hline
\end{tabular}

Tabela 20: Distribuição das personagens por sexo e tipo de citação nas reportagens de política dos telejornais (período eleitoral), excluída a categoria "popular" Obs. Eram possíveis múltiplas respostas, na variável "Tipo de citação".

As personagens são, na sua esmagadora maioria, integrantes do campo político em sentido estrito. Apenas $1,5 \%$ das inserções de política brasileira incluem personagens vinculadas a empresas privadas, apenas 1,6\% integrantes de movimentos sociais. Organizações nãogovernamentais, militares, grupos religiosos, universidades e organizações internacionais são ainda menos presentes. De fato, os integrantes destes grupos estão pouco visíveis nos telejornais como um todo, não apenas no noticiário político, havendo algumas poucas exceções parcais, em geral previsíveis, como a maior presença de personagens vinculadas a universidades nas matérias de ciência e tecnologia, saúde pública, ecologia e educação, de militares em desastres e (acompanhados por internacionais e seitas religiosas) no noticiário internacional.

Os repórteres do sexo masculino ainda predominam no noticiário político, sendo os responsáveis por $40,6 \%$ das inserções, contra apenas $27,2 \%$ de repórteres mulheres (há repórteres de ambos os sexos em 2,8\% das inserções e nas restantes, que são notas, comentários ou editoriais, não há repórteres). Reportagens de política realizadas por mulheres tendem a apresentar uma média maior de personagens masculinas e menor de personagens femininas (quando se observam as reportagens de outras categorias, o resultado é o inverso).

Entre as personagens, predominância masculina fica mais gritante. No noticiário político da TV, aparecem, em média, mais de seis homens para cada mulher. Foram 610 citações ou entrevistas de mulheres (média de 0,47 por inserção), contra 3749 de homens (média de 2,87 por inserções). Em 67,9\% das inserções, não aparece nenhuma personagem feminina, ao passo que os homens estão presentes em 83,9\% delas. Em toda a amostra, apenas 64 inserções, isto é, menos de $5 \%$ do total, apresentaram apenas personagens femininas.

Ao todo, 1086 diferentes "personagens" foram entrevistadas ou citadas nas inserções sobre política brasileira - e mais 257 anônimos, o que quase sempre significa que são populares entrevistados em enquetes do tipo "fala povo", sem identificação por nome. Populares identificados pelo nome, ainda que fosse apenas o prenome, não foram incluídos na categoria.

Quase dois terços das personagens são vinculadas a algum partido político, descando-se aquelas filiadas ao PT (20,4\%) e ao PSDB (12,4\%). O presidente da Repúbli ca e candidato à reeleição, Luiz Inácio Lula da Silva, é a personagem mais citada, presente 372 vezes, isto é, em $30,4 \%$ das inserções sobre política. Conforme mostra a tabela 16, seguem-se outros candidatos presidenciais, o que reflete a prática dos noticiários de fornecer quase que diariamente sua agenda. De fato, os candidatos a presidente somam mais de um quarto das personagens dos telenoticiários. Todos os candidatos aos governos estaduais, por outro lado, mal passaram de $7 \%$.

O restante da lista se divide entre protagonistas dos principais escândalos do período (Luiz Vedoin, Gedi- 
Gênero e políitca no jornalismo brasileiro • $24-39$

\begin{tabular}{|c|c|c|c|c|c|c|c|c|}
\hline & & & & Reuistas & & & & Jomais \\
\hline & Veja & Época & Carta & total & $\mathrm{JN}$ & Record & SBT & total \\
\hline Executivo & $2,0 \%$ & $24,0 \%$ & $47 \%$ & $20,3 \%$ & $0,8 \%$ & $4,1 \%$ & $87 \%$ & $3,8 \%$ \\
\hline Legislativo & $2,6 \%$ & $0,6 \%$ & $1,6 \%$ & $67 \%$ & $38 \%$ & $6,2 \%$ & $36 \%$ & $4,4 \%$ \\
\hline Judiciário & $07 \%$ & $1,9 \%$ & $2,4 \%$ & $15,2 \%$ & $1,5 \%$ & $9,9 \%$ & $2,0 \%$ & $4,1 \%$ \\
\hline Escândalos & $32,2 \%$ & $97 \%$ & $18,9 \%$ & $19,9 \%$ & $27,6 \%$ & $23,6 \%$ & $25,8 \%$ & $26,0 \%$ \\
\hline Eleições (pesquisas) & $8,6 \%$ & $1,9 \%$ & $10,2 \%$ & $25 \%$ & $10,4 \%$ & $7,9 \%$ & $3,2 \%$ & $79 \%$ \\
\hline $\begin{array}{l}\text { Eleições } \\
\text { (curiosidades) }\end{array}$ & $9,9 \%$ & $10,4 \%$ & $27,6 \%$ & $1,2 \%$ & $33 \%$ & $38 \%$ & $10,3 \%$ & $5,1 \%$ \\
\hline $\begin{array}{l}\text { Eleições (debate } \\
\text { eleitoral) }\end{array}$ & $15,1 \%$ & $29,9 \%$ & $13,4 \%$ & $1,4 \%$ & $30,6 \%$ & $33,6 \%$ & $31,3 \%$ & $31,7 \%$ \\
\hline Vida partidária & - & $1,3 \%$ & $7,1 \%$ & $18,9 \%$ & $1,8 \%$ & $3,4 \%$ & $83 \%$ & $3,8 \%$ \\
\hline Sociedade civil & - & $26 \%$ & $0,8 \%$ & $20,3 \%$ & $13 \%$ & $4,8 \%$ & $1,2 \%$ & $2,2 \%$ \\
\hline História & $07 \%$ & $0,6 \%$ & $3,1 \%$ & $67 \%$ & - & - & $0,4 \%$ & $0,1 \%$ \\
\hline Outros/mix & $28,3 \%$ & $16,9 \%$ & $10,2 \%$ & $15,2 \%$ & $19,0 \%$ & $27 \%$ & $5,2 \%$ & $10,8 \%$ \\
\hline
\end{tabular}

Tabela 21: Espaço ou tempo destinado às diferentes subcategorias no noticiário político (período eleitoral)

mar Passos, Valdebram Padilha, Freud Godoy), ministros e líderes da oposição. Heloísa Helena, candidata à presidência pelo P-SOL, é a única mulher entre os 20 mais presentes. Depois dela, vão aparecer a senadora Serys Slhessarenko (27 inserções), a deputada e candidata ao governo fluminense Denise Frossard (17 inserções), a senadora Roseana Sarney (14 inserções), a ministra Dilma Rousseff (13 inserções), a candidata presidencial Ana Maria Rangel (10 inserções) e a deputada e candidata ao governo gaúcho Yeda Crusius (9 inserções).

De fato, excluídas as "anônimas", a candidata Heloísa Helena responde por $31,1 \%$ da presença feminina no noticiário político. Como contraposição, percebe-se que Lula fornece $11,5 \%$ da presença de homens, também excluídos os "anônimos". Isto é, a presença feminina é muito mais concentrada e, na verdade, foi inflada pela circunstância excepcional de haver uma candidata mulher às eleições presidenciais com perspectivas de alcançar uma votação razoável.

Um pouco menos da metade das personagens (44\%) aparece falando. As restantes são apenas citadas pelos apresentadores, repórteres ou por algum entrevistado ${ }^{7}$. As presenças "com voz" foram diferenciadas de acordo com o conteúdo do que era dito:

a. sound-bite com argumento: quando o entrevistado afirma que é contra ou a favor de determinado projeto (ou candidatura, ou situação etc.), acrescentando, ainda que de forma taquigráfica, argumentos que sustentem sua posição;

b. sound-bite com posição: quando o entrevistado afirma que é contra ou a favor de determinado projeto, sem aduzir argumentos em favor de sua posição;

c. sound-bite técnico: quando o entrevistado limita-se a explicar um processo (por exemplo, a tramitação de um projeto legislativo), sem indicar uma posição quanto à sua substância;

d. sound-bite irrelevante: quando a declaração do entrevistado tem caráter meramente anedótico.

Conforme demonstra a tabela 17, entre aqueles que têm acesso à voz, predominam os sound-bites com argumento. Há pouca variação na forma da presença dos integrantes dos três poderes institucionais - um pouco mais de sound-bites técnico-descritivos entre os integrantes do poder judiciário, mas nada que o teste do chiquadrado indique como significativo. Os "populares" concentram os sound-bites irrelevantes, o que já era esperado.

Os sound-bites irrelevantes são mais freqüentes entre as personagens do sexo feminino (tabela 18). Trata-se da diferença mais significativa do ponto de vista estatístico .Parte importante dessa diferença se deve ao fato de que as personagens populares têm um peso muito maior entre as mulheres do que entre os homens (tabela 19). A maior concentração de personagens do poder executivo entre eles e do legislativo entre elas se deve, em grande medida, ao peso das presenças de Lula e de Heloísa Helena, respectivamente.

Retirados os populares da amostra, mulheres e homens mostram um perfil bastante mais similar, no que se refere ao tipo de citação, ainda que elas ainda mostrem um número significativamente superior de sound-bites irrelevantes (tabela 20).

A duração média do sound-bite das personagens femininas, 11,2 segundos, é inferior à das personagens masculinas, que chega a 15,2 segundos. Tal resultado não se 
explica apenas pela presença de personagens populares - retiradas da amostra, os números se aproximam, mas ainda são desfavoráveis às mulheres $(15,7$ contra 16,7 segundos para os homens) - ou de sound-bites irrelevantes - sem eles, os números ficam em 14,4 e 16,3 segundos, respectivamente. Tampouco é uma distorção provocada pelas longas entrevistas em estúdio com os candidatos à presidência, majoritariamente do sexo masculino. Sem elas, o sound-bitefeminino médio cai para 9,1 segundos, bem abaixo do masculino, que fica em 12,6 segundos. Isto é, as mulheres realmente têm menos acesso à voz do que os homens no noticiário político.

\section{Considerações finais}

Os dados preliminares da pesquisa indicam, assim, uma presença reduzida das mulheres em relação aos homens, permitindo observar assimetrias de gênero nas representações do mundo social e, em especial, nas representações da política difundidas pela mídia.

A despeito das diferenças entre os meios - revista semanal e televisão - e entre os próprios veículos singulares, há uma quantidade significativa de coincidências na abordagem do campo político e das distinções de gênero nele presentes. Os meios de comunicação de massa reproduzem e mesmo reforçam a especialização da atividade política, que as instituições da democracia representativa levam a cabo. Têm legitimidade para freqüentar o noticiário político aqueles que estão investidos em cargos públicos, sejam eles eletivos ou de confiança; aos outros - categoria que inclui os próprios espectadores - cabe acompanhar o jogo. Isso fica evidenciado de forma ainda mais clara pela irrelevância dos depoimentos dos "populares", destinados a cumprir um papel meramente ilustrativo, quando não folclórico, sem que se espere que produzam qualquer colaboração pertinente ao debate que se trava entre os atores políticos legítimos.

A política, nas chamadas "democracias representativas", de fato se faz assim, com a exclusão permanente do titular nominal da soberania, o povo. Mas a mídia não se limita a refletir uma realidade que a cerca; ela desempenha uma função ativa na reprodução de práticas sociais. Assim, o telejornal ou a revista semanal não só descrevem uma situação de fato (o monopólio da atividade política pelos profissionais), eles a naturalizam diante de seu público e contribuem para sua perpetuação.

O paralelo entre o noticiário político de revistas e telejornais no período eleitoral, o único para o qual já dispomos de dados comparáveis, mostra perfis muitos semelhantes. As revistas concederam $20,58 \%$ de seu espaço ao tema, enquanto os telejornais, com conteúdo total necessariamente mais reduzido, chegaram a 31,5\% de seu tempo. Observando a distribuição das subcategorias dentro do noticiário político, há uma ênfase similar no debate eleitoral e nos escândalos políticos, com as revistas se dando a luxo de dedicar uma proporção ligeiramente maior de seu espaço às outras subcategorias (tabela 21). Chama a atenção, também, nas revistas, em comparação aos telejornais, a presença maior do noticiário sobre o executivo e menor sobre legislativo e judiciário.

Chama a atenção, ainda, o contraste entre a cobertura da revista Época e do Jornal Nacional, ambos produtos das Organizações Globo. Época, sozinha, faz com que a cobertura sobre o poder executivo seja maior entre as revistas (dedicando 19,4\% do seu noticiário político a ele) e com que a cobertura dos escândalos seja menor (dando a eles cerca de um terço do espaço concedido por CartaCapital, menos de um quarto do espaço concedido por Veja). Já o Jornal Nacionalé, entre os telejornais analisados, o que menos dedica tempo ao poder executivo, com notável distância de seus concorrentes, e o que mais destaque dá aos escândalos. Apenas uma análise mais detida do conteúdo da cobertura permitirá que se avancem explicações: se trata-se de uma notável independência editorial de diferentes veículos da mesma empresa, de duas estratégias diferentes para veicular uma mesma visão de mundo ou, ainda, da velha política de "dar uma no cravo e outra na ferradura".

Assim, a cobertura política é focada no processo eleitoral e nos escândalos produzidos no âmbito dos poderes constituídos. Representantes da sociedade civil estão virtualmente ausentes dos telejornais e pouco aparecem nas revistas. As mulheres são amplamente minoritárias, respondendo por $19,6 \%$ das aparições nas revistas (no conjunto dos três períodos) e $22,8 \%$ nos telejornais. Tais freqüências, porém, escondem uma desigualdade ainda mais brutal, já que, em proporção muito maior do que os homens, essas mulheres tendem a ser "populares" cuja presença no noticiário político é apenas incidental. Além disso, há uma concentração muito significativa das aparições em uns poucos nomes excepcionais - Heloísa Helena, Marta Suplicy ou Dilma Rousseff.

Se esses dados indicam características das representações da política nos noticiários, é importante destacar que o campo político, por sua vez, não é um microcosmo da sociedade mais ampla. Aqueles que a ele pertencem possuem características que os distinguem da média do público; entre elas, o fato de que a elite política tende a ser, em sua grande maioria, masculina. Visto até pouco tempo atrás como "natural", isto é, como decorrência de diferenças inatas entre os sexos, esse viés é hoje reconhecido como sendo um problema a ser resolvido, por intermédio de ações como, por exemplo, as políticas de cotas eleitorais.

Convém assinalar que os obstáculos para o ingresso e o sucesso - das mulheres na política não se limitam àqueles gerados no próprio campo. Seu comprometimento com a gestão do espaço doméstico e com o cuidado com a família dificulta que assumam carreiras profissionais que, como a política, exigem flexibilidade de horários, uma disponibilidade quase inesgotável de tempo e ausências freqüentes. Por conta disso, as mulheres encontram maior dificuldade para militar em movimentos sociais ou partidos ou para fazer campanha eleito- 
ral. Se eleitas, têm menos condições de se dedicar ao exercício do mandato. Além disso, sua ascensão é prejudicada pelo fato de que a possibilidade de assumir um cargo que as obrigue a se afastar da família gera um dilema que é virtualmente inexistente para os homens. Mecanismos de incentivo à participação política são necessários, mas as condições para o exercício paritário do poder dependem ainda de creches, da divisão das tarefas domésticas e do fim da discriminação de gênero no mercado de trabalho.

Dependem também de condições mais igualitárias de acesso aos espaços de geração de capital político. Os meios de comunicação de massa são, sob esse ponto de vista, um elemento crucial. Ao reproduzir acriticamente o modelo sexista predominante no campo político, o noticiário contribui para reforçá-lo. Ao difundir uma representação do mundo da política como uma esfera especializada, restrita a poucos e quase que exclusivamente masculina, reforça os preconceitos que afastam as mulheres - e outros grupos subalternos - da ação política e, em específico, da disputa eleitoral mamecos

\section{NOTAS}

* Este artigo integra a pesquisa "Determinantes de gênero, visibilidade midiática e carreira política no Brasil", financiada pelo CNPq (editais n ${ }^{\circ} 45 / 2005$ e $\left.n^{\circ} 61 / 2005\right)$. Ele se beneficia de discussões ocorridas após a apresentação de dados parciais da pesquisa, em seminários na Universidade de Brasília, na Universidade de São Paulo, no Centro Brasileiro de Análise e Planejamento (São Paulo), no II Congresso da Associação Brasileira de Pesquisadores de Comunicação e Política, em Belo Horizonte, e no XVII Encontro da Compós, em São Paulo no Grupo de Trabalho “Comunicação e Política”, em junho de 2008.

** Fonte das tabelas: pesquisa "Determinantes de gênero, visibilidade midiática e carreira política no Brasil"

1. Utilizaremos, ao longo do paper, as expressões "campo da mídia" e "campo midiático", para designar o espaço de visibilidade gerado pelos veículos de comunicação e as injunções vinculadas aos seus interesses empresariais; e "campo jornalístico", referindo-nos a um subcampo específico, com grande significado para a visibilidade política.

2. Sobre o ponto, ver Bickford (1996, pp. 97-8).

3. A coleta e tabulação dos dados foi realizada por uma extensa equipe de estudantes da Universidade de Brasília. Helena Máximo e Janine Mello, mestrandas em Ciência Política, colaboraram na coordenação do trabalho. Carlos Machado, então também mestrando, ajudou na programação do software. Entre os muitos graduandos que se engajaram no trabalho, gostaríamos de agradecer especialmente àqueles que contribuíram mais extensamente: Andrea Azevedo, Bianca Caldas, Bruno Nogueira, Carla Beatriz, Cleiton de Lima, Fernanda Feitosa, Janaína Figueira, Luiz Augusto Campos, Mariana Abreu, Marina Braga, Natanael Lopes, Natália Vieira, Nathália Mattos, Paula Lima e Tiago Amaral.

4. As gravações dos telejornais ficaram a cargo da ANDI - Agência de Notícias dos Direitos da Infância, cuja colaboração, em especial na pessoa de Railssa Alencar, agradecemos.

5. A unidade de medida de espaço foi a "página", fracionada em "meia página”, " quarto de página” etc.

6. Cumpre lembrar que a unidade de análise foi a matéria (reportagem, entrevista etc.). Se uma personagem era citada várias vezes na mesma matéria, ainda assim era contabilizada apenas uma presença.

7. Usamos "entrevistado" por comodidade, mas, a rigor, pode se tratar também de um trecho de uma declaração pública, de um discurso no plenário, de uma gravação clandestina etc.

\section{REFERÊNCIAS}

BICKFORD,S. The dissonance of democracy: listening, conflict, and citizenship. Ithaca: Cornell University Press, 1996.

BOURDIEU, P. La distinction: critique sociale du jugement. Paris: Minuit, 1979. 1983.

Questões de sociologia. Rio de Janeiro: Marco Zero, . Meditações pascalianas. Rio de Janeiro: Bertrand Brasil, 2001.

MIGUEL, L. F. Os meios de comunicação e a prática política. Lua Nova, no 55-6. São Paulo, 2002, pp. 155-84.

. Representação política em 3-D: elementos para uma teoria ampliada da representação política. Revista Brasileira de Ciências Sociais, no 51 . São Paulo, 2003, pp. 123-40.

YOUNG, I. M. Polity and group difference: a critique of the ideal of universal citizenship, em PHILLIPS, A. (ed.). Feminism and politics. Oxford: Oxford University Press, 1998.

Inclusion and democracy. Oxford: Oxford University Press, 2001. 